\title{
Capitalism and the global economic crisis
}

\begin{abstract}
The global crisis with which the contemporary capitalist today is faced highlights many dilemmas and open questions. One of the most important is the definition and analysis of the forces on which capitalism has survived and developed. Without answering these questions, it is not possible to establish real, long-term, strategic solutions, while such answers are likely to be effective only if all social actors approach consensus. Today, 'capitalism' is an umbrella term for the economic, political and social order in most developed European countries, as well as in so-called 'transition countries', including Serbia, where the process of establishing capitalism is not yet finished. In essence, with the exception of a small number of societies, which are relics of the past, there are no states which have yet to take the first steps toward capitalism. A comparative analysis of these countries would confirm many common characteristics but, at the same time, many differences, favouring the conclusion that, within 'capitalism', we have essentially different systems.
\end{abstract}

Keywords: capitalism, transition, crisis, humanist philosophy, social justice

\section{Introduction}

The global crisis stretching out over several years presents itself as an earthquake for the modern world and most developing countries and countries in transition alike: all are directly faced with difficult economic, social and moral consequences as a result of the contradictions facing present-day capitalism. In other words, research and policy has come to occupy the centre of attention in the economic and social crisis of the 'global village', and it will be so until the world permanently exits the crisis and embarks on a path of stable economic and social progress, with benefits for all citizens, or until the power of research and ethics has been able permanently to establish its superiority over the sources of the crisis.

A little more than two decades ago, a wall across Europe impeding the creation of that 'global village' was torn down. Symbolically and practically, the obstacles that these societies faced on their way towards a new model of social order, based on private ownership, competition, multi-party parliamentary democracy and human freedoms and rights, have been removed. Capitalism thus definitively completed its global character. However, there were other obstacles and open questions which are inevitable in such a complex, lengthy and contradictory social process as the transition. They knew only the basic values - of private property, ever-existing competition, the match between human capabilities and knowledge, democracy, freedom and human rights. However, the pathways and the social costs of this process are unknown even today, after two decades of transition; we can say that these are different, but that the final success of the transition can be measured by a single parameter - its social cost. 
Today, at the beginning of the twenty-first century, the basic civic values mentioned above are not in dispute in capitalist societies; they are the indisputable achievements of modern civilisation. This confirms that these are now accepted, in western Europe as in countries in transition, as a permanent value embedded within the political and economic systems of modern states. However, behind these indisputable matters and these permanent, civilised values, called 'capitalism', civil society is hiding different themes. This resembles some sort of time machine, in which countries are in different cells or at different stages of capitalist development. This imposes a need to redefine the term 'modern capitalism', which must take into account the changed parameters, i.e. that modern civilisation has raised objective criteria related to a definition of economic and technological development, living standards and a world of dignity, social justice, solidarity, freedom of personality, human rights and freedoms.

Redefining the term 'modern capitalism', to be a new way to approach the phenomenon of the crisis in the capitalist mode of production, in the quest for an answer to the question whether the current global crisis is the turning point in the history of capitalism, is to question whether the future course of social events might turn in other directions. What politicians and researchers now agree upon is the belief that the world after the crisis will not be the same.

We can not deny that the capitalist world, since the Great Depression in 1929, has been embarked on an anti-crisis policy which has sought to link the optimal principles of competition and the principles of social justice and solidarity. At the superficial level, it is evident that capitalist society is changing and we can not talk today about capitalism in the same way that we did just a few decades ago. The current crisis is proving its strength and identifies that these changes were not sufficient to neutralise the sources and consequences of the current crisis. It is clear that many facts speak in favour of this crisis, in its duration and effects, surpassing that of the Great Depression in 1929.

Based on this analysis, we can outline one conclusion - that the capitalist social order has, in general, been in a transition process for decades and that the transition countries of central and eastern Europe have only opened up new aspects of this global process.

Of course, such a generalised statement poses a series of new questions, as well as a large number of repeated old ones to which we have not given satisfactory answers in recent decades. However, all these questions may, ultimately, become concentrated into one - what is the vision of this transition, with regard to its strategic goals, and what parameters can be assessed realistically to the achievement of those goals? This implies that we must deal with the question of whether this transition means the end of the familiar forms of capitalism, or indeed of capitalism in general (Stiglitz, 2003).

\section{Capitalism in a time dimension}

Today's crises in the time of capitalism inevitably raise the question of the driving forces and sources of energy on the basis of which capitalism, as the dominant social order, has evolved and survived in the past few centuries. The answer to that question today is for everyone - researchers, politicians, economists, experts in various fields, entrepreneurs, owners of capital, trade unions, workers: for all citizens. It is impossible not to answer that question if we are to find a real, long-term and strategic response to 
the ways and methods of overcoming the crisis and its social and moral costs. In this regard, perhaps the biggest issue of modern times, we can confirm the essence and meaning of the Latin wisdom handed down over two thousand years: historia magistra vita est. Nevertheless, it is not only about obtaining a sufficient answer, because any answer will not be effective if it does not attract the support of all the actors previously mentioned.

That capitalism has spread the soil on which it was created - the United Kingdom, western Europe and America have developed different versions and different forms of it - thus confirming its strength and vitality and its global, universal values. It is also apparent from the outset that capitalism has reached various achievements in individual countries and regions in the world. The highest degree of development, as measured by economic and technological development, the development of science and education and, on this basis, the quality of life of the people, has been made by capitalism in its countries of origin - within Europe and north America.

Modern capitalism is, however, characterised by a negative feature - increasing differences between rich and poor. This tendency has been present from the first steps of capitalism but, instead of reducing them, it has widened them farther and farther. The modern age is characterised by a remarkable increase in the dynamics of these differences which are designated, by all relevant actors globally, as a source of industrial and social conflict and the biggest obstacle to a lasting, stable path out of the crisis.

This tendency towards exhibiting an almost identical problem in different countries, regions and the world at large, leads us to the conclusion that this negative trend has spread at all levels with the expansion of capitalism. No answer to these questions of social science, policy and strategy development will mean that we will not be able to offer a relevant policy response to the resolution of the crisis. Social theory has been intensively involved in searching for answers to these questions since the Great Depression in 1929, and it is still one of the biggest challenges for social theory, policy and strategy for economic and social development in modern times. The global economic crisis has only emphasised the complexity and conflictual nature of these issues. Recent research knowledge, experience and social practices provide a basis for further research in this area, focusing on the following questions:

- is the constantly expansion of the gap between rich and poor the result of systematic errors of capitalism?

- is this systematic error of capitalism inevitable, meaning that a substantial proportion of the global population was, is and will in the future be doomed to poverty?

- what is the real power and the economic and technological perspectives of developing countries which may allow them to change the rules that keep them in a vicious circle of poverty?

This process flow is different in its dynamics, while the results enrich the undisputed practices of capitalism. However, the planet resembles a time machine on which the stations, put together on one time line, represent certain historical stages of capitalism. The state, or degree, of the development of capitalism in individual countries and regions of the world is largely similar, even identical to the characteristics of certain stages through which today's economically and technologically most advanced countries of the world have already passed. Thus, the term 'capitalism' involves a political, 
economic and social order (as it always does in general) in the most developed European countries; in south-eastern Europe, which are defined as countries in transition (which means that the process of building capitalism as a complete social system in these countries, encompassing also Serbia) has not yet been completed; the US and Canada; Latin America; Asia; and Africa. In fact, except for a small number of traditional countries, which are frequently relics of the past, there is almost no country on the planet that has not yet made at least the first steps towards developing capitalism. Comparative analysis of these systems confirms a number of key common denominators but, in many cases, an insufficient number of arguments to prove that these constitute various systems. Also, such a comparative analysis would show the extent to which these different systems in the development phase of capitalism, or in terms of the different variants of the capitalist system, may contribute to the long-term stabilisation of some countries and regions of the world.

The consequence is that actual differences in the nature and degree of the development of capitalism in particular countries and regions may be transferred to a logicalconceptual plan, in the sense that 'capitalism' means different terms or, in other words, a whole range of concepts which include among them the stage at which capitalist civilisation exists at a particular point in time. This means that there is a chance to debate various aspects of capitalism and that, to the participants in the discussion, the term means the different essences of capitalism. This difference is not only logical and theoretical but also factual, and refers to multiple differences in the level of economic development and living standards between various capitalist countries.

These differences range very widely, encompassing capitalism in the Nordic countries, which belong among the economically and technologically most advanced countries with the highest standards in the world, developed within the 'Swedish model of socialism.' In this regard, we should recall that a cluster of prominent philosophers of the sixties and seventies (including Karl Korsch, Gyorgy Lukács, Herbert Marcuse, Ernst Bloch, Predrag Vranicki, Mihailo Markovic and Zagorka Golubovic) developed humanistic philosophy and the concept of a new society based on the principles of social justice and solidarity, within the thesis of a 'convergence of the system.' If history is a teacher of life, then it directs us to the method of analysis of each of these models of capitalism and, from each of the developmental stages involved in all of them, the drawing of one essential driving, but fundamentally negative, characteristic (Sen, 1999).

The basis for such an analytical approach is that capitalism, especially in the second half of the twentieth century, underwent profound changes. In other words, capitalism as a system is in transition, but the dynamics of this has enhanced the particular character of conflict in a time of crisis. This transition is multi-layered, covering several aspects of capitalism in the global order as a whole, as well as trends in individual countries, which are located at lower stages of development. It can be argued that these countries are moving, or are at least trying to move, at the rate of economically and technologically advanced capitalist countries and to apply their models of the political, economic and social organisation of society. However, this time of transition is never identical. Rather, it is characterised by a range of different varieties. 
It also imposes a need to identify the common denominators that appear at all stages of development, and in all periods and all forms of capitalism; in other words, the level of integration of those forces which, at all these stages, represents the backbone, the driving force of capitalism and integration. It is a landmark that primarily refers to the allocative power of the market. It is undeniably a fact about capitalism, more or less agreed by adherents of different theoretical and ideological orientations, that it is the market - or, more precisely, competition - that, in the past few centuries, has confirmed capitalism's creative and driving force. It has proved to be a huge, but not inexhaustible, source of energy for dynamic economic and technological development and is based on the quality and standard of living of a growing number of people. Awareness that fierce competition prompts only the best to survive encourages entrepreneurs, by force of economic necessity, to promote all the parameters of production and services - individual and group productivity, efficiency and profitability, thus generally multiplying the creative power of human labour.

The market has a strong regulatory function because, in the long run, a balance between supply and demand is the basis for stable economic development. However, this regulatory function does not command in all periods the same power and resources. Over a long period of time, the regulatory function of the internal market has only dependent sources of power, stemming from the character of capitalist modes of production based on the market. However, due to the effect of a whole range of economic and non-economic factors, the autonomous regulatory power of the market is becoming weaker and more frequent crises, and longer ones, are leading to more difficult political, economic, social and moral consequences and causing radical industrial and social conflicts.

This conclusion is confirmed by the current global economic crisis, which began four years ago, in 2008, and which, according to the more optimistic estimates of analysts, will last for a further three years; while more pessimistic predictions state that it will last another decade. If, on the basis of the available documentation and historical accounts are gathered all the cyclical crises of the capitalist mode of production, it would be disconcerting to find that capitalist civil society, for an important part of its history, has spent its time in a state of crisis which has contributed to a number of political, economic, social and moral consequences. This is one of the key determinants of the process which is defined herein as the ongoing transition of capitalism.

One of the factors that has influenced the course of this process of the transition of capitalism is that the market is mainly, or exclusively, treated as an economic phenomenon. This does not of course mean that there are no social, ethical, legal or other aspects to the study of markets, but it is indisputable in economic theory that development strategies, economic policy and social consciousness have been dominated by the economic aspect. Thus, in any analysis of the causes and consequences of the crisis of the capitalist mode of production, it is the economic factors which are dominant, or even the only ones taken into account, while the strategies emerging from the crisis are concentrated mainly, or solely, on economic measures (Hase et al, 2005).

Not taken at all into account, or only insufficiently so, are other aspects of the market which, in conjunction with the economic aspects, form the core of the market model, not only offering a combination of mutual demand relationships but a set of complex, 
dynamic and contradictory social processes. This limited access is contrary to the very essence of the market and also closes off those strategies that would otherwise work towards a prevention of the resource crisis of the capitalist mode of production. In this, the importance of two aspects must be stressed.

First of all, the processes that take their place in the economic life of society, as an integral part of overall social life, can be objectively analysed only in association with those processes which operate within political, legal, cultural and other spheres of social life. In this sense, those processes which are functioning in the market belong among those social processes which are only most visible at the start point, or where their expression is at the peak of the positive and negative social processes in general.

In addition, we need to focus on what, first of all, economists, and then researchers in other fields of social life, have already realised; that is, the need to segment the market into three main segments - market goods; capital; and labour. The three segments of the market as a whole each function on the basis of market relations and processes, but each one has its own characteristics.

In analysing the transition of capitalism, which encompasses the sum of all the processes and contradictions through which capitalism is passing, the functioning of labour markets, or the specific restrictions related to the functioning of supply and demand in this area, is particularly important. The laws of supply and demand lie at the basis of the market economy. It is known that an increase in supply leads to falling prices while, conversely, demand which is greater than supply causes higher prices. Theoretically, due to supply issues, the prices of certain goods, services and money can fall to zero. However, in the labour market this is not possible. Labour costs may fall to a subsistence level, which indicates the quantity of material goods that workers and their families need to implement, at the most basic level, the simple reproduction of the labour force. Nevertheless, should this happen, it inevitably leads to the most radical forms of industrial and social conflicts and crises, and the final collapse of such a social order, as a result of the internal driving forces of this system no longer being sufficient to propel self-reproduction. It is understood that this specific determinant in the functioning of the labour market significantly affects, in turn, the functioning of commodity markets and capital markets.

Intrinsically linked with that is another determinant of the functional relationship of the mutual interdependence of markets and commodities, capital and labour. The specific, essential element of the functioning of the laws of supply and demand is that competition essentially always matches the situation of human capabilities and knowledge. Namely, the level of appearance visibly corresponds with various goods and services, money and customers, according to the required and desired characteristics of particular goods and services (technological, economic, practical and aesthetic), which will determine producers to give their trust. It is clear that this does not compete with the variety of goods, services and money which are the subject of competition but, nevertheless, the people who are involved in competition start from the basic idea of producing certain goods, or developing the technology and work organisation; while technologists are choosing the most suitable materials; designers are making a certain kind of appreciable design; and others are connecting with an optimum production and 
organisational system. That is why competition has, over the decades, moved into the fields of education and science, and into the field of 'the struggle for human souls'.

\section{Instead of a conclusion - the search for sustainable solutions}

Over two hundred years ago Adam Smith, one of the founders of the classical school of political economy, noted in his book On the sources of the wealth of nations that today it was indisputable that the 'source of wealth is the human labour of the people', before going on to analyse the market and its driving mechanism. Of course, he would have had no idea that his thoughts would be one of the values and ideological foundations of modern capitalist societies, as well as one of the strongest and, most importantly, permanently growing sources of industrial and social conflict. Neither did he foresee that the modern company would seek a permanent ending of the key contradictions in the capitalist mode of market-oriented production between the creative, universal, dynamic and developmental nature of human work and the restrictions of production methods. In any case, neither was it his fault that many people throughout history, including in relation to the market today, have declared him a 'holy grail' regarding the sole and exclusive control of relationships in the economic life of society which, ultimately, represents a conflict with the principles of common sense. In much the same way, for example, Alfred Nobel, the inventor of dynamite, can not be held responsible for the actions of the many who have abused dynamite for the purposes of killing people and destroying material goods, which was certainly not his intention.

In any case, one can not deny that capitalist countries, especially since the Great Depression in 1929, since which time the state has definitely become one of the key and indispensable factors in the economy, have been compelled to develop anti-crisis policies. In contrast, anti-crisis policies are being constantly reinforced with the introduction of new instruments as well as the amplification of their intensity. Many of these 'anti-crisis instruments' have long since ceased to be in the narrow sense of the phrase; and are coming to be applied consistently as an integral part of development strategy and economic and social policy. What is also characteristic of the most powerful instruments and the effective practice of anti-crisis policies among economically and technologically powerful countries is a clear connection to anti-crisis measures and stable development. However, a critical analysis of this process can confirm that, since 1929, all have essentially applied the same anti-crisis instrument: just as a doctor has kept on increasing the dosage for high temperature, thereby leading to the state of the underlying disease which has caused the higher temperature to be maintained or worsened.

The current global crisis can, in this sense, serve as an effective means of practical training - of course, for anyone who wants to learn. For example, it is clear that Germany, France, Italy and other developed countries have applied numerous measures of anti-crisis policy - through tax policy; by lowering the discount rate at the national bank; and implementing a variety of incentives for entrepreneurship and employment - but it was obviously not enough, because the mechanism of crisis has prevailed and things have got out of control.

From this a conclusion does arise. Effective strategies for crisis prevention, or the reduction of their consequences, should obviously not be limited to the economic as- 
pects. Perhaps the economy is important, but it is clearly insufficient. On the contrary, the flow of current events, as in previous crises, confirms that the world we live in needs a new philosophy; a new system of social values. From this new philosophy may be derived essentially a new approach to economics, politics and development strategies which will, in the long-term, lead to success and an overcoming of the causes of the crisis and the opening up of a new phase of prosperity.

This new philosophy, which is emerging as we all search for ways out of the crisis, is, in essence, creating an element of the new philosophy, the philosophy of transition to capitalism. This is now predominant, but it must inevitably take into account the following components. These are, primarily, the non-economic factors of the market. Within this, we have in mind that the market, or the laws of supply and demand, represent other than economic factors: the market and the market economy represent a philosophy and a way of life; a world view of society; an understanding of material and other values; a moral system. All these elements must be brought into conformity with a social system that is functional, developmental, economically efficient and socially just. And it's simply not true that the economic and market components of this system are always and exclusively the dominant characteristics on which we need to focus.

This is corroborated by the changes in the structure of labour costs in the transition to capitalism. Namely, in the early stages of capitalist development, labour costs included only the so-called 'subsistence minimum', i.e. the quantity of material goods required for the simple reproduction of the workforce and to meet basic needs. Today, economics, sociology and strategies for sustainable development are essentially the new parameters of what can be defined as a civilised minimum. This means that the cost of labour today is a spectrum of requirements and criteria for civilisation - the right to work; to decent earnings; healthy and safe working conditions; education; health; social care; and to other requirements which, today, are among the indisputable achievements of modern civilisation. It is an indisputable trend in the current process of the transition of capitalism. New technologies, which are the manifestations of the growing creative power of human labour, work in the new structure as a creative development process, providing a structure for the new world of work within the financial and logistical basis of that process. If the social order is unable to respond to that challenge, then civilisation has no future.

\section{References}

Bloch, E (1970) Princip nade Kultura: Beograd.

Hase, R, H. Šnajder and K. Vajgelt (2005) Leksikon socijalne tržišne privrede Fondacija Konrad Adenauer: Kancelarija u Beogradu.

Institut društvenih nauka (2008) Moral i ekonomija, Zbornik radova sa istoimenog naučnog skupa održanog u Beogradu Institut društvenih nauka: Beograd.

Smith, A (2003) O izvorima bogatstva naroda Centar za liberalno-demokratske studije: Beograd.

Sen, A (1999) Development as freedom Anchor Books, Random House: New York. 
Stiglitz, J (2003) The roaring nineties Penguin Books: London.

Stubbs, R and R. D. G. Underhill (1994) Political economy and the changing global order St. Martin Press: New York. 